\title{
Seasonality of pathogenic fungi in mites of rubber tree plantations adjacent to fragments of Cerrado
}

\author{
Demite, $P R{ }^{\mathrm{a}, \mathrm{b} *}$ and Feres, RJF.

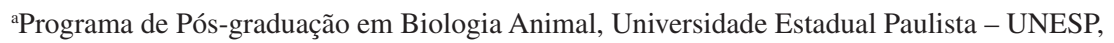 \\ Rua Cristóvão Colombo, 2265, Jardim Nazareth, CEP 15054-000, São José do Rio Preto, SP, Brazil

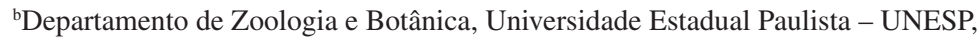 \\ Rua Cristóvão Colombo, 2265, Jardim Nazareth, CEP 15054-000, São José do Rio Preto, SP, Brazil \\ *e-mail: peterson_demite@yahoo.com.br \\ Received January 2, 2007 - Accepted February 27, 2007 - Distributed August 31, 2008
}

(With 3 figures)

\begin{abstract}
Fungi are the most frequently observed pathogens of mite populations, helping to control them on different crops. Twenty-five samples of leaves were collected from rubber tree plantations adjacent to two fragments of Cerrado vegetation. Each rubber tree plantation had 25 plants selected for sampling and seven leaves from around each tree top were collected up to seven to eight meters above ground. Approximately 250 individuals of Calacarus heveae Feres, Phyllocoptruta seringueirae Feres, and Tenuipalpus heveae Baker, collected randomly, were mounted from each plantation. Hirsutella thompsoni Fisher was observed on all three mites and T. heveae was the most infected species. The highest infestation levels occurred from November to February (rainy season). In the dry season, infestation levels were below 5\%. Hirsutella thompsonii has potential to be used as mycoacaricide during the rainy season.
\end{abstract}

Keywords: Hevea brasiliensis, Hirsutella thompsonii, natural occurrence, Neozygites.

\section{Ocorrência sazonal de fungos patogênicos em ácaros de seringais vizinhos a fragmentos de Cerrado}

\section{Resumo}

Fungos são os patógenos mais freqüentemente observados em populações de ácaros, auxiliando o controle destes em diferentes culturas. Vinte e cinco amostras de folhas foram coletadas de cultivos de seringueiras vizinhas a dois fragmentos de vegetação de Cerrado. Em cada seringal, 25 plantas foram selecionadas para coletas e sete folhas ao redor da copa foram coletadas até a altura de sete a oito metros do solo. Aproximadamente 250 indivíduos de Calacarus heveae Feres, Phyllocoptruta seringueirae Feres e Tenuipalpus heveae Baker, coletados aleatoriamente, foram montados. Hirsutella thompsonii Fisher foi observado nas três espécies de ácaros e T. heveae foi a espécie mais infectada. Os maiores níveis de infecção ocorreram de novembro a fevereiro (estação chuvosa). Na estação seca, os níveis de infecção ficaram abaixo dos 5\%. H. thompsonii tem potencial para ser usado como micoacaricida na estação chuvosa.
\end{abstract}

Palavras-chave: Hevea brasiliensis, Hirsutella thompsonii, ocorrência natural, Neozygites.

\section{Introduction}

Fungi are the most frequently observed pathogens of mite populations, helping to control them on different crops (Alves, 1998). One of the most important genera of mite pathogenic fungi is Hirsutella Pat., which has been found particularly on Eriophyidae (Lipa, 1971; McCoy, 1996; Alves, 1998; Poinar-Jr. and Poinar, 1998; Van der Geest et al., 2000; Van der Geest et al., 2002). Van der Geest et al. (2000) observed nine species of Hirsutella attacking phytophagous mites of the families Eriophyidae,
Tenuipalpidae, Tetranychidae and Tydeidae; Hirsutella thompsonii Fisher has been the most studied of all species of this genus (Baker and Neunzig, 1968; Samson et al., 1980; McCoy, 1996; Poinar-Jr. and Poinar, 1998).

In rubber trees [Hevea brasiliensis (Willd. ex Adr. De Juss.) Müell. Arg., Euphorbiaceae], H. thompsonii has been reported causing considerable mortality of Calacarus heveae Feres (Acari, Eriophyidae) (Tanzini et al., 2000). Van der Geest et al. (2002) and 
Bellini et al. (2005) also observed the occurrence of $H$. thompsonii on $C$. heveae.

The aim of this study was to quantify the fungal infection rate on $C$. heveae, Phyllocoptruta seringueirae Feres (Acari, Eriophyidae) and Tenuipalpus heveae (Baker) (Acari, Tenuipalpidae) in rubber tree plantations adjacent to fragments of Cerrado vegetation.

\section{Materials and Methods}

The study was conducted in two plantations of rubber tree clone PB 235. One of them was close to a type of Cerrado (sensu Ribeiro and Walter 1998) called "Cerradão" (17 $23^{\circ} \mathrm{S}$ and $\left.54^{\circ} 42^{\prime} \mathrm{W}\right)$ and the other was next to a type of Cerrado called "Riparian Forest" $\left(17^{\circ} 22^{\prime} \mathrm{S}\right.$ and $\left.54^{\circ} 41^{\prime} \mathrm{W}\right)$, both in Itiquira, southern Mato Grosso State. The first plantation was about 17 ha and the second, about 45 ha. In both cases, samples were taken from 25 trees selected for collection from an area of about $20,000 \mathrm{~m}^{2}$, close to the respective Cerrado fragments.

Between March 2004 and March 2005, samples were taken at about 14 day intervals, totalling 25 sampling events. At each sampling date, seven leaves were taken from around the canopy of each selected tree up to seven to eight meters above ground; one foliole of each leaf was analyzed. Approximately 250 individuals, each of the usually most abundant mite species on rubber trees in the region $(C$. heveae, $P$. seringueirae, and $T$. heveae, according to Demite and Feres, 2007a), from each field, were mounted in Hoyer's medium + Aman blue (1:1) to determine the fungal infection rates.

The Spearman correlation coefficient (rs) was used to identify a possible relationship between fungal infection rate and climatic data registered at Plantações E. Michelin Ltda., located about 3,8 km from the first and $2,8 \mathrm{~km}$ from the second plantation.

\section{Results}

In both plantations, the fungi $H$. thompsonii and Neozygites sp. (Figure 1) were found infecting mites of the three species analyzed in this study. This is the first record of fungal infection on $P$. seringueirae and T. heveae. The rate of infection by $H$. thompsonii was much higher than the rate of infection by Neozygites sp., which was below $1 \%$ of infected individuals.

The highest infection rates by $H$. thompsonii were concentrated in two periods: from March to June 2004 and from November 2004 to March 2005 (Figure 2). Between July and October, $H$. thompsonii infection rates were below $5 \%$. During this period, rainfall was very scanty: no rain occurred during 65 days between July and September (Figure 3).

Fungal infection rate by $H$. thompsonii correlated positively with precipitation $(\mathrm{rs}=0.061 ; \mathrm{P}=0.003$ ) and relative air humidity $(\mathrm{rs}=0.57 ; \mathrm{P}=0.005)$, but not with temperature $(\mathrm{rs}=0.38 ; \mathrm{P}=0.084)$ or with the mean number of sunlight hours per day ( $\mathrm{rs}=-0.01 ; \mathrm{P}=0.962$ ).
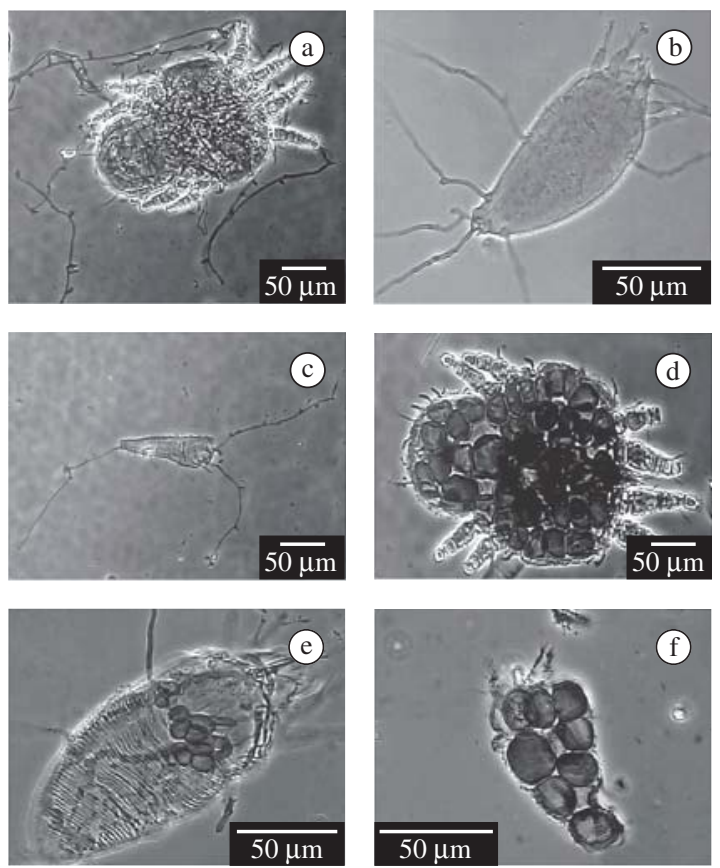

Figure 1. Fungi infecting the most abundant mites in rubber tree: Hirsutella thompsonii a-c): a) Tenuipalpus heveae; b) Calacarus heveae, and c) Phyllocoptruta seringueirae; Neozygites sp. d-f): d) Tenuipalpus heveae; e) Calacarus heveae, and f) Phyllocoptruta seringueirae.

Due to the natural senescence of the leaves, the samples collected between July and August were not considered for the correlation analysis.

The highest $H$. thompsonii infection rates of $C$. heveae and T. heveae were observed in the plantation near the Cerradão fragment, whereas the highest infection level of $P$. seringueirae was observed in the plantation near the Riparian Forest. T. heveae was the species with the highest infection rates in both areas: $23.7 \%$ of all analyzed individuals of this species were infected by H. thompsonii (Table 1).

\section{Discussion}

Precipitation can enhance the development of H. thompsonii. Infection rates were much higher in rainy months than in months with low or no precipitation. The same outcome was observed for $H$. thompsonii and Neozygites cf. floridana on Mononychellus tanajoa (Bondar) (Acari, Tetranychidae) and Oligonychus gossypii (Zacher) (Acari, Tetranychidae) in Benin, Africa (Yaninek et al., 1996). The highest rates were also observed when the temperature remained between 23.9 and $25.7{ }^{\circ} \mathrm{C}$. In a previous study, the epizootia of $H$. thompsonii in $C$. heveae was observed when the mean monthly temperature ranged from 22.6 to $25.1^{\circ} \mathrm{C}$ (Tanzini et al., 2000). For Alves and Lecuona (1998), these data are close to the ideal situation for development 
Table 1. Percentage of individuals of phytophagous mite species infected by Hirsutella thompsonii, in rubber tree plantations adjacent to Cerrado fragments in Itiquira, Mato Grosso state, Brazil.

\begin{tabular}{cccc}
\hline Species & CF plantation & RF plantation & Both plantations \\
\hline Calacarus heveae & 17.46 & 14.48 & 15.51 \\
Phyllocoptruta seringueirae & 9.11 & 9.57 & 9.39 \\
Tenuipalpus heveae & 26.76 & 21.31 & 23.65 \\
\hline
\end{tabular}

CF: Cerradão fragment; RF: Riparian Forest fragment.

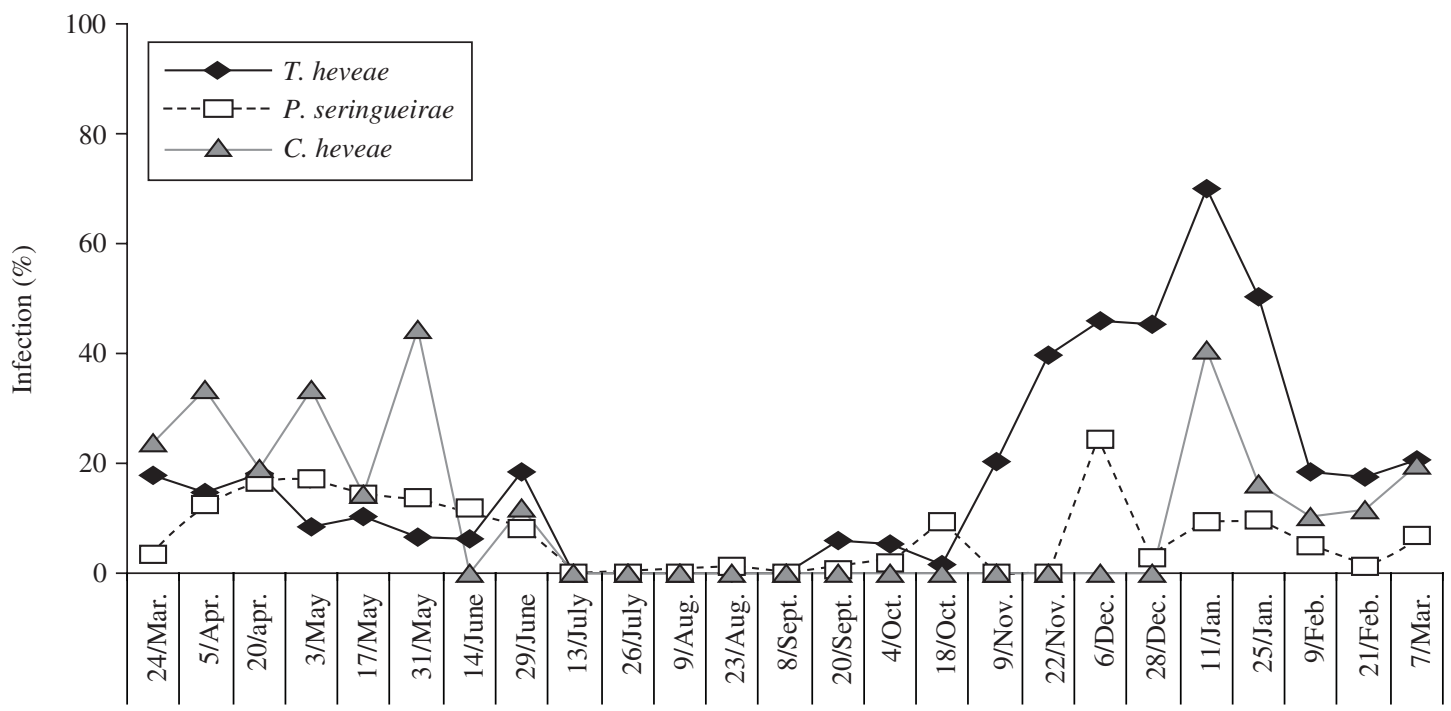

Collections

Figure 2. Percentage of mites belonging to the three species infected by $H$. thompsonii in Itiquira, Mato Grosso state, Brazil. Bar: senescence period.

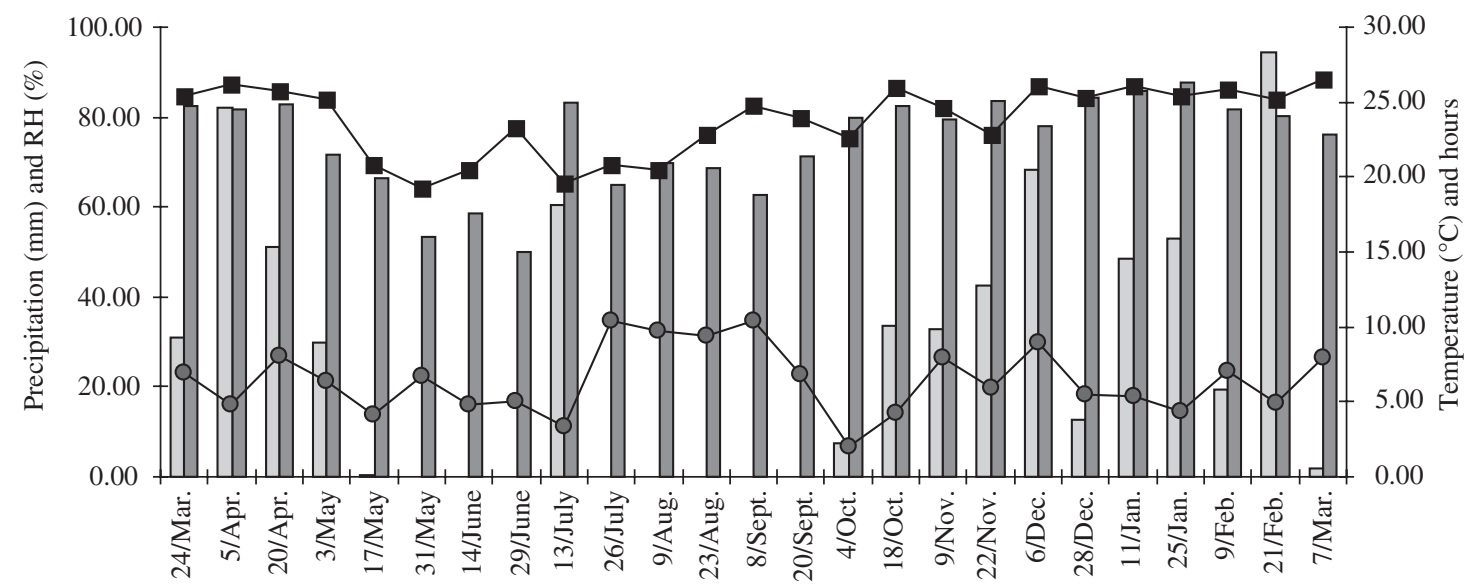

Collections

$\varpi$ Precipitation $\sqsubset$ Mean RH $\multimap$-Mean temperature $\multimap-$ Sunlight hours

Figure 3. Climatic dates observed during the five days prior to each sampling date in Itiquira, Mato Grosso state, Brazil. 
of pathogenic fungi. Periods of high relative air humidity can also enhance the development of $H$. thompsonii.

The use of naturally occurring pathogens for pest integrated management systems depends on the adoption of techniques that promote a good epizootic development, such as the reduction in the application of chemical products. Natural control agents can lead to a significant decrease in the number of chemical applications that growers normally make, with benefits for the environment, as well as for the direct and indirect impacts on life and health quality (Pereira et al., 1998).

Demite and Feres (2007b) found that mites belonging to the families Tetranychidae, Tenuipalpidae and Tydeidae were also infected by $H$. thompsonii in native plants of fragments adjacent to the rubber tree plantations. The surrounding vegetation might be a reservoir for these pathogens. The conidia can be dispersed by the wind from native vegetation areas to rubber tree plantations.

Future research, including field and laboratory tests, should be conducted to verify the potential of $H$. thompsonii as mycoacaricide of the most numerous species of phytophagous mites in rubber trees.

Acknowledgements - To Dr. Richard A. Humber (USDAARS, Ithaca, USA) for the identification of the pathogenic fungi; Plantações E. Michelin Ltda. (Itiquira, MT, Brazil) for the fellowship and for sponsoring the project; Cássio J.H. Scomparim and Fernando S. Fonseca, agronomists at Plantações E. Michelin Ltda., for their support throughout the project. To the anonymous reviewer for the valuable suggestions for this paper.

\section{References}

ALVES, SB., 1998. Fungos entomopatogênicos, p. 289-391. In ALVES (Ed.). Controle microbiano de insetos. Piracicaba: Fealq. 1163 p.

ALVES, SB. and LECUONA, RE., 1998. Epizootiologia aplicada ao controle microbiano de insetos, p. 97-170. In ALVES SB. (Ed.). Controle microbiano de insetos. Piracicaba: Fealq. 1163 p.

BAKER, JR., NEUNZIG, HH., 1968. Hirsutella thompsonii as a fungus parasite of the blueberry bud mite. J. Econ. Entomol., vol. 61 , no. 4 , p. $1117-1118$.

BELLINI, MR., MORAES, GJ. and FERES, RJF., 2005. Ácaros (Acari) de dois sistemas de cultivo da seringueira no noroeste do Estado de São Paulo. Neotrop. Entomol., vol. 34, no. 3, p. 475-484.

DEMITE, PR. and FERES, RJF., 2007a. Ocorrência e flutuação populacional de ácaros associados a seringais vizinhos de fragmentos de Cerrado. Neotrop. Entomol., vol. 36, no. 1, p. $117-127$.

-, 2007b. Influência de fragmentos de Cerrado na infecção fúngica em ácaros de seringueiras. Arq. Inst. Biol., vol. 74, no. 3, p. 271-273.

LIPA, JJ., 1971. Microbial control of mites and ticks, p. 357-373. In BURGES, HD. and HUSSEY, NW. (Eds.). Microbial control of insects and mites. London: Academic Press. 861 p.

McCOY, CW., 1996. Pathogens of eriophyoid mites. p. 481-490. In LINDQUIST, MW., SABELIS, MW. and BRUIN, J. (Eds.). Eriophyoid mites: their biology, natural enemies and control. Amsterdan: Elsevier Science. 822 p.

PEREIRA, RM., ALVES, SB., SOSA-GÓMEZ, DR. and MACEDO, N., 1998. Utilização de entomopatógenos no Manejo Integrado de Pragas. p. 1097-1118. In ALVES SB. (Ed.). Controle microbiano de insetos. Piracicaba: Fealq. 1163 p.

POINAR-Jr, G. and POINAR, R., 1998. Parasites and pathogens of mites. Annu. Rev. Entomol., vol. 43, p. 449-469.

RIBEIRO, JF. and WALTER, BMT., 1998. Fitofisionomias do bioma Cerrado. p. 89-166. In SANO, SM. and ALMEIDA, SP. (Eds.). Cerrado: ambiente e flora. Planaltina: Embrapa-CPAC. $556 \mathrm{p}$.

SAMSON, RA., McCOY, CW. and O'DONNELL, KL., 1980. Taxonomy of the acarine parasite Hirsutella thompsonii. Mycologia, vol. 72, no. 2, p. 359-377.

TANZINI, MR., ALVES, SB., TAMAI, MA., MORAES, GJ. and FERLA, NJ., 2000. An epizootic of Calacarus heveae (Acari: Eriophyidae) caused by Hirsutella thompsonii on rubber trees. Exp. Appl. Acarol., vol. 24, no. 2, p. 141-144.

VAN DER-GEEST, LPS., MORAES, GJ., NAVIA, D. and TANZINI, MR., 2002. New records of pathogenic fungi in mites (Arachnida: Acari) from Brazil. Neotrop. Entomol., vol. 31, no. 3, p. 493-495.

VAN DER-GEEST, LPS., ELLIOT, SL., BREEUWER, JAJ. and BEERLING, EAM., 2000. Diseases of mites. Exp. Appl. Acarol., vol. 24, no. 7, p. 497-560.

YANINEK, JS., SAIZONOU, S., ONZO, A., ZANNOU, I. and GNANVOSSOU, D., 1996. Seasonal and habitat variability in the fungal pathogens, Neozygites cf. floridana and Hirsutella thompsonii, associated with cassava mites in Benin, West Africa. Biocontrol Sci. Technol., vol. 6, no. 1, p. 23-33. 